\title{
Pengetahuan Sikap, dan Perilaku Ibu Terhadap Sirkumsisi pada Anak Perempuan
}

\author{
Dian Milasari, Dyah Tunjungsari, Elisa Harlean, Erick Wonggokusuma, Faisal Adam, \\ Henry Riyanto, Rini Sekartini, Corry Wawolumaya. \\ Departemen Ilmu Kesehatan Anak Fakultas Kedolteran Universitas Indonesia RS Dr. Cipto Mangunkusumo, \\ Jakarta
}

Latar belakang. Situasi mengenai pola sirkumsisi (sunat) perempuan di Indonesia masih belum banyak diketahui, sehingga mengakibatkan kurang pengetahuan masyarakat Indonesia. Beberapa tahun terakhir WHO telah menyatakan menentang segala bentuk medikalisasi sirkumsisi perempuan.

Tujuan. Mengetahui pengetahuan, sikap, dan perilaku ibu mengenai sirkumsisi pada perempuan di Jakarta.

Metode. Desain penelitian cross-sectional dengan menggunakan metode convenient sampling. Data diperoleh dari kuesioner yang diisi sendiri oleh para ibu (self administered questionnaire).

Hasil. Hampir seluruh responden melakukan sirkumsisi pada anak perempuan mereka 97,2\% dari 106 orang responden. Agama merupakan alasan utama melakukan sirkumsisi 61,2\%. Surat edaran dari Departemen Kesehatan RI mengenai larangan bagi tenaga medis untuk melakukan sirkumsisi pada anak perempuan tidak diketahui oleh sebagian besar responden (83\%). Orang tua atau teman menjadi sumber yang paling berkesan untuk melakukan sirkumsisi 34\%. Sedangkan dari tenaga medis, informasi yang paling berkesan datang dari perawat atau bidan 21,7\%. Sebagian besar sirkumsisi dilakukan pada usia di bawah 5 tahun. Bidan merupakan pelaku sirkumsisi pada sebagian besar anak $73,9 \%$. Sebagian besar responden memiliki tingkat pengetahuan rendah $(87,7 \%)$, sikap kurang $(90,6 \%)$, dan perilaku kurang $(78,3 \%)$.

Kesimpulan. Hampir seluruh anak perempuan responden disirkumsisi (97,1\%). Mayoritas responden memiliki pengetahuan, sikap, dan perilaku yang kurang mengenai sirkumsisi pada anak perempuan $(87,7 \%, 90,6 \%$, dan 78,3\%). Sirkumsisi dilakukan seluruhnya pada usia di bawah 5 tahun, terutama karena alasan agama. Pelaku sunat pada anak perempuan adalah bidan. Delapanpuluhtiga persen responden tidak mengetahui tentang surat edaran Departemen Kesehatan mengenai larangan medikalisasi sunat pada perempuan. (Sari Pediatri 2008;10(4):242-5).

Kata kunci: pengetahuan, sikap dan perilaku, sirkumsisi anak perempuan, ibu.

Alamat Korespondensi:

DR. Dr. Rini Sekartini Sp.A(K). Divisi Tumbuh Kembang - Pediatri Sosial. Departemen Ilmu Kesehatan Anak FKUI-RSCM Jl.Salemba No 6, Jakarta 10430

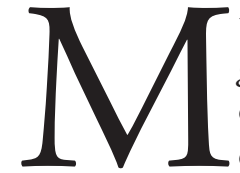

utilasi genital perempuan (female genital mutilation) atau lebih dikenal dengan sirkumsisi pada perempuan dilakukan atas dasar budaya atau 
indikasi non-terapeutik. Sirkumsisi pada perempuan saat ini dianggap sebagai suatu diskriminasi dan telah dinyatakan melanggar Convention on the elimination of all forms of discrimination against women (CEDAW) dan Convention against torture and other cruel, inhumane or degrading treatment or punishment (United Nations, 1995). ${ }^{1}$ Dilaporkan WHO memperkirakan lebih dari 130 juta orang perempuan telah disirkumsisi, dan diperkirakan 3 juta anak perempuan berisiko disirkumsisi setiap tahunnya. Saat ini terdapat kecenderungan peningkatan angka sirkumsisi perempuan di Eropa dan Amerika, terutama pada kaum imigran. ${ }^{2}$

Masyarakat Indonesia saat ini masih memiliki banyak mitos mengenai sirkumsisi, namun sirkumsisi pada anak perempuan belum teruji kebenarannya. Mitos tersebut antara lain agar kelak nafsu seksual tidak berlebihan serta tidak menjadi perempuan yang genit dan mengejar laki-laki. Selain itu, dipercaya bahwa sirkumsisi pada anak perempuan termasuk dalam tuntunan agama (Islam) walaupun sebetulnya tidak didapatkan dalil yang kuat.

Dalam suatu survei yang dilakukan Budiharsana $\mathrm{dkk}^{1}$ terhadap 1694 ibu di beberapa daerah di Indonesia, hampir seluruhnya kecuali di Kutai menyatakan dirinya telah disirkumsisi dan menyaksikan sirkumsisi. Ditemukan 69\% ibu menyatakan sirkumsisi memiliki manfaat, yaitu menuntaskan kewajiban agama dan juga bermanfaat untuk kesehatan dan higienitas. Hanya sebagian kecil yang menyatakan tidak ada manfaat dari sirkumsisi sedangkan 26\% lain menjawab tidak tahu. Delapanpuluh persen responden di Padang, Sumenep, dan Kutai, rata-rata menyebutkan masa neonatus dan bayi adalah masa paling ideal dilakukan sirkumsisi, di Gorontalo $80 \%$ sirkumsisi dilakukan pada usia 1-4 tahun, sedangkan di Makasar dan Bone sirkumsisi dilakukan pada usia 5-9 tahun. ${ }^{1}$

Variasi juga didapatkan pada pelaku sirkumsisi pada beberapa daerah di Indonesia. Mayoritas ibu di daerah Serang, Sumenep, dan Gorontalo menggunakan jasa dukun bayi, sedangkan di Makassar dukun sunat lebih berperan. Dari total 2215 kasus yang dilaporkan dari berbagai daerah yang diteliti, sebanyak $68 \%$ kasus dilakukan oleh para dukun tradisional dan sisanya dilakukan oleh tenaga kesehatan terutama bidan. ${ }^{1}$ Badan kesehatan dunia WHO telah menentang segala bentuk medikalisasi sirkumsisi perempuan dan memperingatkan tenaga kesehatan untuk tidak melakukan sirkumsisi perempuan. ${ }^{1,2}$

\section{Metode}

Penelitian survei cross-sectional menggunakan kuesioner yang telah diuji coba, kuesioner diisi oleh para ibu atau dibantu dengan peneliti. Penelitian dilakukan pada tanggal 11 Juni - 6 Juli 2007. Populasi adalah ibu yang memiliki anak perempuan usia 0-18 tahun di Jakarta. Subjek penelitian adalah ibu di wilayah kerja Posyandu Kampung Melayu pada bulan Juni 2007, yang memenuhi kriteria inklusi. Didapatkan 106 ibu yang dipilih menggunakan teknik convenient sesuai dengan kriteria.

Data yang didapat diolah dengan SPSS 12 untuk mengetahui hubungan antara varibel bebas dan terikat. Variabel bebas terdiri dari usia, pendidikan, pekerjaan ibu, tingkat pendapatan, agama, dan sumber informasi. Variabel terikat adalah pengetahuan, sikap, dan perilaku ibu.

\section{Hasil}

Dari 106 orang responden, hampir seluruhnya (97,2\%) melakukan sirkumsisi pada anak perempuanya. Mayoritas menyatakan agama $(61,2 \%), 34$ orang (33\%) memilih alasan kesehatan, dan sisanya $(5,8 \%)$ memilih budaya atau adat istiadat sebagai alasan dilakukannya sirkumsisi pada anak perempuan.

Sebagian besar responden (83\%) tidak mengetahui akan adanya surat edaran dari Departemen Kesehatan RI mengenai sirkumsisi pada anak perempuan. Surat ini berisi larangan bagi tenaga medis untuk melakukan sirkumsisi pada anak perempuan. Ibu yang mengetahui keberadaan surat edaran ini 17\% (Tabel 2).

Sumber informasi mengenai sirkumsisi pada anak perempuan yang paling berkesan bagi sebagian besar responden bukan berasal dari tenaga medis. Orang tua atau teman menjadi sumber yang paling berkesan (34\%), kemudian diikuti oleh pemuka agama $(20,8 \%)$ dan pemangku adat $(1,9 \%)$. Sedangkan dari tenaga medis, informasi yang paling berkesan mengenai sunat pada anak perempuan datang dari perawat atau bidan (21,7\%), diikuti dokter Puskesmas (17\%) dan dokter praktik pribadi $(4,7 \%)$.

Responden yang memiliki pengetahuan kurang mengenai sirkumsisi pada anak perempuan 93 orang $(87,7 \%)$, yang memiliki pengetahuan sedang 12 orang $(11,3 \%)$, dan responden yang memiliki pengetahuan 
baik hanya 1 orang $(0,9 \%)$. Responden memiliki sikap yang kurang terhadap sunat pada anak perempuan 96 orang $(90,6 \%)$, yang memiliki sikap baik dan sedang masing-masing berjumlah 5 orang $(4,7 \%)$. Untuk sebaran perilaku didapatkan responden berperilaku kurang 83 orang $(78,3 \%)$, sedang 20 orang $(18,9 \%)$, dan baik 3 orang $(2,8 \%)$. (Tabel 1 dan 2 )

\section{Diskusi}

Secara umum, pengetahuan dipengaruhi oleh sumber informasi, tingkat pendidikan, status sosial ekonomi, pengalaman, pengaruh lingkungan sekitar dan kemauan individu untuk mencari tahu. Selanjutnya, pengetahuan akan mempengaruhi sikap dan perilaku. Definisi sirkumsisi secara umum adalah pemotongan seluruh dan sebagian prepusium atau kulit depan. ${ }^{3}$ Salah satu pertanyaan adalah dampak sirkumsisi. Sirkumsisi pada perempuan memiliki konsekuensi medis jangka pendek dan jangka panjang. Besarnya konsekuensi bergantung pada metode sirkumsisi, keahlian pelaku sirkumsisi, alat yang digunakan, lingkungan, dan kondisi fisik dari perempuan itu sendiri. Sirkumsisi dapat menyebabkan kematian akibat syok hemoragik akibat perdarahan masif, syok neurogenik akibat nyeri hebat, trauma, infeksi dan sepsis. Seringkali anak perempuan menjadi syok akibat nyeri hebat dan trauma psikologis. ${ }^{2,4-6}$

Dampak lain adalah dampak secara seksual. Penelitian di Sudan memperlihatkan orgasme terjadi pada perempuan yang telah disirkumsisi, meskipun terdapat penurunan prevalensi dari 90\% ketika mereka masih muda menjadi $10 \%$ setelah memiliki seorang anak. $^{7,8}$

Hampir seluruh responden (97,2\%) melakukan sirkumsisi pada anak perempuannya. Selanjutnya seluruh responden melakukan sirkumsisi pada anak perempuannya saat anak tersebut berusia di bawah 5 tahun. Hal ini sesuai dengan penelitian Budiharsana $\mathrm{dkk}^{1}$ yang dilakukan di beberapa daerah di Indonesia pada anak yang berusia 15-18 tahun, hampir seluruh anak perempuan (86\%-100\%) telah disirkumsisi. Pada penelitian tersebut juga dilaporkan lebih dari 90\% responden di daerah Sumenep dan Padang melakukan sirkumsisi pada anak perempuan saat anak di bawah usia 5 tahun dengan alasan utama adalah identifikasi religius. Usia anak saat melakukan sirkumsisi sangat bervariasi dari satu daerah ke daerah lain. Tindakan tersebut dilakukan pada bayi yang

Tabel 1. Karakteristik anak perempuan responden yang disirkumsisi

\begin{tabular}{llcc}
\hline Variabel & Kategori & Frekuensi & Persentase \\
\hline Usia saat sirkumsisi & $<5$ tahun & 106 & 100. \\
Pelaku sunat & Dokter & 32 & 22,5 \\
& Bidan & 105 & 73,9 \\
& Dukun bayi & 2 & 1,4 \\
& Dukun sunat & 1 & 0,7 \\
& Lain-lain & 2 & 1,4 \\
\hline
\end{tabular}

$\mathrm{n}=106$

Tabel 2. Pengetahuan dan perilaku mengenai sirkumsisi pada anak perempuan

\begin{tabular}{llcc}
\hline Variabel & Kategori & Frekuensi & Persentase \\
\hline Usia dilakukan sunat (tahun) & $<5$ & 98 & 92,5 \\
& $\geq 5$ & 3 & 2,8 \\
& Tidak tahu & 5 & 4,7 \\
Alasan menyunat & Agama & 63 & 61,2 \\
& Budaya/adat istiadat & 6 & 5,8 \\
\multirow{3}{*}{ Surat edaran Depkes } & Kesehatan & 34 & 33,0 \\
& Tahu & 18 & 17,0 \\
& Tidak tahu & 88 & 83.0 \\
\hline
\end{tabular}


berusia beberapa hari, anak perempuan, remaja, dan terkadang perempuan dewasa. ${ }^{1,5} \mathrm{Hal}$ lain yang juga berpengaruh sirkumsisi merupakan suatu tradisi yang dilakukan secara turun-temurun pada suatu populasi masyarakat, sehingga anggota masyarakat tersebut akan melakukan kebiasaan yang dilakukan oleh lingkungan sekitarnya. Sumber informasi responden yang paling berkesan berdasarkan data dapat dikategorikan berasal dari medis dan non-medis. Sumber informasi yang berasal dari tenaga medis $43,3 \%$ sedangkan dari sumber non-medis $56,7 \%$. Informasi responden yang paling berkesan berasal dari sumber non-medis terutama dari orangtua dan teman (34\%). Dari hal ini diduga bahwa sebagian besar responden memperoleh informasi tentang sirkumsisi pada perempuan secara turun temurun.

Berdasarkan data yang didapatkan, tenaga kesehatan merupakan pelaku sunat tersering $(96,4 \%)$, terutama bidan. Sedangkan penelitian Budiharsana dkk menunjukkan di berbagai daerah di Indonesia sebanyak 68\% sirkumsisi dilakukan oleh tenaga tradisional (dukun sunat dan beranak). ${ }^{1} \mathrm{Hal}$ ini menunjukkan kurangnya sosialisasi mengenai pelarangan medikalisasi sirkumsisi pada anak perempuan khususnya bagi tenaga kesehatan. Terdapat $83 \%$ responden yang tidak mengetahui adanya surat edaran dari Departemen Kesehatan mengenai larangan medikalisasi terhadap sirkumsisi pada anak perempuan, sehingga praktik sirkumsisi pada anak perempuan masih banyak dilakukan.

\section{Kesimpulan}

Prevalensi sirkumsisi pada anak perempuan 97,1\%, seluruh responden menyunat anak perempuannya pada usia di bawah 5 tahun, karena alasan agama. Sebagian besar responden memiliki pengetahuan kurang, sikap kurang dan perilaku yang kurang mengenai sirkumsisi pada anak perempuan. Sumber informasi yang paling berkesan adalah sumber informasi non medis $(56,7 \%)$ terutama orang lain (orang tua, tetangga, dan teman). Pelaku sunat sebagian besar pada anak perempuan adalah bidan. Sebagian besar responden tidak mengetahui tentang surat edaran Departemen Kesehatan mengenai larangan medikalisasi sunat pada perempuan. Maka disarankan perlu dilakukan sosialisasi mengenai surat edaran Departemen Kesehatan mengenai larangan medikalisasi sirkumsisi pada anak perempuan kepada tenaga kesehatan seperti dokter, perawat dan bidan, serta kepada masyarakat umum. Selain itu, perlu dilakukan penelitian lanjutan di populasi umum dengan karakteristik yang lebih bervariasi setelah dilakukan sosialisasi mengenai larangan sirkumsisi pada anak perempuan.

\section{Daftar Pustaka}

1. Budiharsana M, Amaliah L,Utomo B, Erwinia. Female circumcision in indonesia: extent, implications and possible interventions to uphold Women's Health Rights. Jakarta: Pop Council; 2004:22-6.

2. WHO information fact sheet No 241. June 2000. Diunduh dari http://www.who.int/mediacentre/factsheets/ fs241/en/. Diakses tanggal 13 Juni 2007

3. Hartanto $\mathrm{H}$, penyunting. Kamus kedokteran Dorland. Edisi 29. Jakarta:Penerbit Buku Kedokteran EGC. 2000. h.438.

4. American Academy of Pediatrics. Female genital mutilation: Committe on Bioethics. Pediatrics 1998; 102:153-6.

5. UNICEF. Child protection from violence, exploitation, and abuse. Diunduh dari http://www.unicef.org/protection/ index_genitalmutilation.html. Diakses tanggal 13 Juni 2007

6. Female genital mutilation and obstetric outcome: WHO collaborative prospective study in six African countries. Lancet 2006;367:1835-41.

7. UN Office for the coordination of humanitarian affairs. Razor's Edge - the controversy of female genital mutilation, IRIN 2007. Diunduh dari http://www.irinnews.org/ InDepthMain.aspx?InDepthId $=15 \&$ ReportId $=624$. Diakses tanggal 13 Juni 2007

8. Female genital cutting. Diunduh dari http://en.wikipedia. org/wiki/Female_genital_cutting.html. Diakses tanggal 13 Juni 2007 